\title{
Comparison of the performances of Nero Siciliano pigs reared indoors and outdoors. 1. Growth and carcass composition
}

\author{
Carolina Pugliese ${ }^{\mathrm{a}, *}$, Giuseppe Madonia ${ }^{\mathrm{b}}$, Vincenzo Chiofalo ${ }^{\mathrm{c}}$, Saverio Margiotta ${ }^{\mathrm{b}}$, \\ Anna Acciaiolia ${ }^{a}$, Gustavo Gandini ${ }^{\mathrm{d}}$ \\ a Dipartimento di Scienze Zootecniche dell'Università di Firenze, Via delle Cascine 5, 50144, Firenze, Italy \\ ${ }^{\mathrm{b}}$ Istituto Sperimentale Zootecnico per la Sicilia, Via Roccazzo 85, 90136 Palermo, Italy \\ ${ }^{\mathrm{c}}$ Dipartimento MO.BI.FI.PA. Facoltà di Medicina Veterinaria, Polo Universitario Annunziata, 98168 Messina, Italy \\ ${ }^{\mathrm{d}}$ Dipartimento di Scienze e Tecnologie Veterinarie per la Sicurezza Alimentare, Università di Milano, Via Celoria 10, 20133 Milan, Italy
}

Received 27 March 2002; received in revised form 29 May 2002; accepted 16 October 2002

\begin{abstract}
A total of 78 female and male Nero Siciliano pigs were used. Forty-one pigs were reared following the traditional management system, 37 pigs were reared in pens with a small outdoor paddock and fed to appetite using commercial rations according to the growing period. Both male and female pigs were castrated. All pigs were weighed and measured periodically. Body measurements included height at withers, chest girth, body length, width at shoulders and at rump. Age and body weight at slaughter ranged respectively from 371 to 572 days and from 79 to $113 \mathrm{~kg}$. The carcasses were weighed and dissected into lean, fat and bone cuts. In the early and final stages indoor-pigs grew faster than those reared outdoors. Trends in body length were similar for the two rearing systems, for width at shoulders and rump, chest girth and height at withers, indoor pigs showed higher values than the outdoor ones. Carcasses of similar weight were longer in outdoor than in indoor pigs but the latter showed greater subcutaneous fat thickness. Outdoor pigs had the lowest dressing percentage and the highest percentage of lean cuts, such as shoulder and ham, but not of neck and loin. Sex did not significantly affect the analysed characteristics.
\end{abstract}

(C) 2003 Elsevier Science Ltd. All rights reserved.

Keywords: Nero Siciliano; Pig; Outdoor; Morphological measures; Carcass composition

\section{Introduction}

There are no reliable data on the performance of most endangered local pig breeds. The evaluation of these performances will help in assessing the conservation value of these breeds. Considering that resources for conservation are scarce, breed performance has been suggested as a criterion to be used in the selection of breeds for conservation (Ruane, 1999). Moreover, performance evaluation may reveal characteristics of the breed that can be used to increase its economic value and, consequently, its self-sustainability. It is known that local breeds often decline because of lack of economic competitiveness (Gandini \& Giacomelli, 1987).

\footnotetext{
* Corresponding author. Tel.: +39-055-3288263; fax: + 39-055321216.

E-mail address: carolina.pugliese@unifi.it (C. Pugliese).
}

Among the numerous pig breeds and ecotypes present in Italy at the beginning of the last century, only five survived the industrialisation of pig breeding, though with small population numbers (Gandini, Fortina, Franci, Madonia \& Matassino, 2001). Among these, the Nero Siciliano pig is today farmed in a restricted area of Sicily, with about 700 sows. Its survival is characterised by both the possibility of obtaining quality meat products and its adaptation to an harsh environment (Chiofalo \& Zumbo, 2001). Although the breed is probably still declining in numbers, these characteristics are giving rise to renewed interest.

The literature on performances of local pig breeds reared under extensive systems is still scarce (Mayoral, Dorado, Guillèn, Vivo, Vàzquez, \& Ruiz, 1999; Serra et al., 1998; Legault et al., 1996). Mayoral et al. (1999) suggested that non-selected genotypes, such as Iberian pigs, could be ascribed to a slow maturing type in as much as bone tissue growth continues at ages older than 
in improved genotypes. Establishing the performances of local breeds may involve both consistent differences between rearing environments and of interactions between management and breed characteristics. Thus comparisons of breeds in different environments is needed. For example, the Iberian pig reaches maturity (160 $\mathrm{kg}$ live weight) under the traditional extensive system in 16-18 months, but this period can be reduced to $12-14$ months if appropriate feed integration is provided when natural pastures are depleted (Dobao, Rodrigagñez, Silio, \& Toro, 1988). Greater differences can be observed by comparing extensive and intensive rearing systems. This theme has been investigated in improved breeds in relation to environment protection and animal welfare (Berger, Dagorn, Le Denmat, Quillien, Vaudelet, \& Signoret, 1997; Enfält, Lundström, Hansson, Lundeheim \& Nyström, 1997; Jonsäll, Johansson \& Lundström, 2001; Van der Wal \& Mateman, 1993).

It is conceivable that comparisons of theperformances of the Nero Siciliano pig in the traditional low input and in higher input farming systems may help to understand breed characteristics and to increase the use of the breeds. The aim of this investigation was to study the effects of the traditional extensive and the indoor rearing systems on growth, performances and carcass characteristics of this breed.

\section{Materials and methods}

A total of 78 female and male Nero Siciliano pigs were used. Forty-one pigs, from six herds, born from July to December, were reared following the traditional management system. All herds were located on the Nebrodi mountains in Sicily. The feeding was based on natural pastures, which included woods mainly composed of the Quercus genus ( $Q$. ilex, $Q$. virgiliana, $Q$. gussonei, $Q$. cerris, $Q$. suber and, more rarely, $Q$. robur) and beech trees (Fagus selvatica), grasslands and Mediterranean bush. In periods of low pasture availability, feeding was supplemented with cereals and field beans
(Vicia faba). Thirty-seven pigs were born and reared in pens with a small outdoor paddock and, after weaning, fed with commercial mixtures according to the growing period (Table 1). To avoid mating with free-ranging boars and to follow the traditional management system, both males and females were castrated at about 3 months of age.

All pigs were weighed and measured periodically, from weaning to slaughter, with a minimum interval of 2 months between measurements. Body measurements included height at withers, chest girth, body length, width at shoulders and at rump. Pigs were slaughtered at different ages and weights, in order to consider the traditional pig farming characterised by slaughtering during the winter months and by the production of carcasses suitable for meat production. Age and body weight at slaughter ranged respectively from 371 to 572 days and from 79 to $113 \mathrm{~kg}$ (Table 2). After slaughter, the thickness of outer and inner layers of backfat on the dorsal midline opposite to the first and last ribs, and to the point over the M. gluteus medius where the backfat is thinner, was recorded. Carcass length and chest deep were taken according to the ASPA (1991) procedure. The day after slaughter carcasses were weighted and right sides were dissected into lean, fat and bone cuts.

Data were analysed using the following linear model (SAS, 1997):

$$
Y_{i j k}=\mu+R_{i}+S_{j}+b_{i} \times X_{i j k}+e_{i j k}
$$

where $Y_{i j k}$ is the $k$ th observation of the $i$ th rearing system $(R)$ and of the $j$ th sex $(S), \mu$ is the overall mean, the $b_{i}$ term is the regression coefficient of the covariate $(X)$ and $e_{i j k}$ is the error which is an independent random variable. The covariate, age or carcass weight depending upon the parameter considered, was tested up to third degree equation. To study the development growth pattern, body measurements were analysed as a function of live weights, by means of the allometric function $Y=\mathrm{aX}^{\mathrm{b}}$ (Huxley, 1932). Analysis was performed on data transformed logarithmically $\left(\log _{10}\right)$.

Table 1

Chemical composition of the diet in different growth stages (percentage on wet basis)

\begin{tabular}{lcccc}
\hline & & Starter (70-105 days) & Growing (106-260 days) & Fattening (261-450 days) \\
\hline Dry matter & $\%$ & 13 & 13 & 13 \\
Crude protein & $\%$ & 19 & 18.20 & 16.5 \\
Ether extract & $\%$ & 5.8 & 5 & 5 \\
Crude fibre & $\%$ & 3.5 & 4.3 & 5 \\
Ash & $\%$ & 5.8 & 5.39 & 6 \\
Lysine & $\%$ & 1.4 & 1.1 & 0.85 \\
Vitamin A & $\mathrm{U} . \mathrm{I} / \mathrm{kg}$ & 12.600 & 12.600 & 12.600 \\
Vitamin D3 & $\mathrm{U.I} / \mathrm{kg}$ & 1.260 & 26 & 1.260 \\
Vitamin E & $\mathrm{mg} / \mathrm{kg}$ & 26 & 154 & 26 \\
Copper & $\mathrm{mg} / \mathrm{kg}$ & 154 & 60 & 100 \\
Sodium salinomycin & $\mathrm{mg} / \mathrm{kg}$ & 60 & & 60 \\
\hline
\end{tabular}


Table 2

Mean age and weight at slaughter

\begin{tabular}{lcr}
\hline & \multicolumn{1}{c}{ Indoor } & Outdoor \\
\hline No. of animals & 37 & 41 \\
Age at slaughter (days) & 448.14 ; range 371-474 & $486.45 ;$ range 420-572 \\
Weight at slaughter (kg) & 101.96 ; range 78.8-123 & 88.25 ; range 66.6-113 \\
\hline
\end{tabular}

\section{Results and discussion}

Trends of live weight in relation to age are shown in Fig. 1. During the first 120 days, indoor-pigs grew faster than outdoor ones. From 120 to 300 days, indoor and outdoor growth trends were parallel. Subsequently, growth rates diverged and indoor-pigs grew faster with an average daily gain of $400 \mathrm{~g}$ in the last 100 days, $280 \mathrm{~g}$ higher than registered in the previous 100 days. Outdoor-pigs showed an average daily weight gain of $200 \mathrm{~g}$ during the entire rearing period, almost constant until 480 days of age, when it showed a decrease. In Iberian pigs Mayoral et al. (1999), observed daily gains during fattening periods which were twice as high as those in the previous periods. However, outdoor growth in different regions cannot be compared because of differences in acorn productivity. Lower growth performances in outdoor versus indoor rearing have been observed independent of food supply in both commercial (Enfält et al., 1997) and local breeds (Labrou, Goumy, Gruand, Mourot, Neelz, \& Legault, 2000). These differences have been related to the higher energy requirements for physical exercise and thermoregulation in outdoor pigs (Enfält et al., 1997). Figs. 2-4 illustrate, for both indoor and outdoor pigs, the changes in body measurements in relation to age. Trends in body length were similar in the two rearing systems. For all other measurements, width at shoulders and rump, chest girth and height at withers, indoor pigs showed greater values than the outdoor ones, in accord with their greater live weight gain, as shown by estimated means (Table 3 ).

In Table 4 the allometric coefficients of body measurements are shown. These coefficients allow one to better understand the evolution of body proportions with growth. The isoauxesis condition of a linear measurement with respect to another of third degree, such as live weight, is expressed by the allometric coefficient of 0.333 (Walstra, 1980), instead of unity, and lower or higher coefficients indicate, respectively, slower or faster relative growth. For width at shoulders, width at rump and chest girth, in both outdoor and indoor pigs, we observed rates that were faster than live weight, that corresponded to late growth. Similar observations were reported for another Italian local breed, the Cinta Senese (Acciaioli, Pugliese, Bozzi, Campodoni, Franci, \& Gandini, 2002; Campodoni, Acciaioli, Bozzi, Pugliese \& Franci, 1998). No significant differences in allometric coefficients were observed between the rearing systems with respect to width at shoulders, width at rump and chest girth, but height at withers and body length were

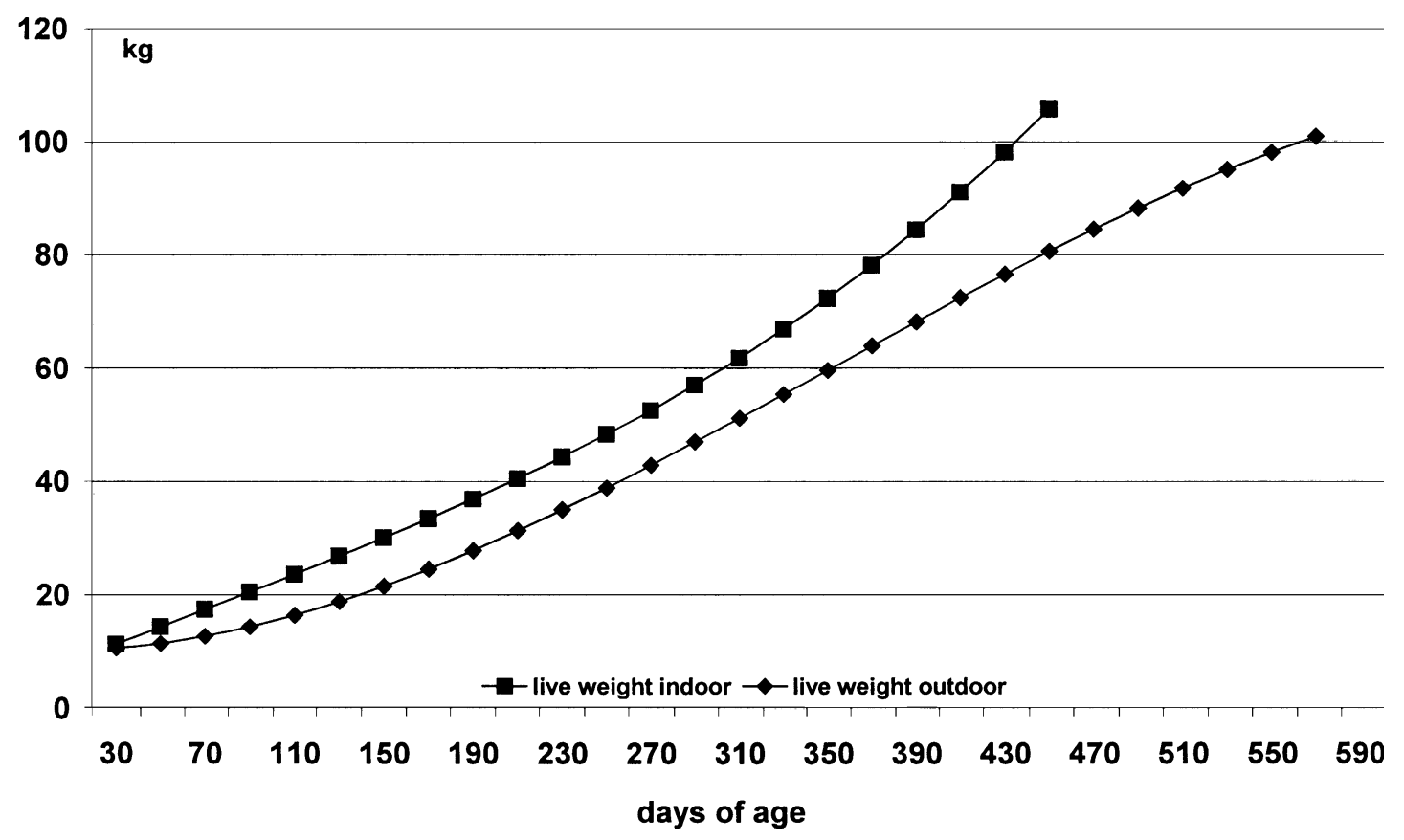

Fig. 1. Live weight as a function of age (days). 


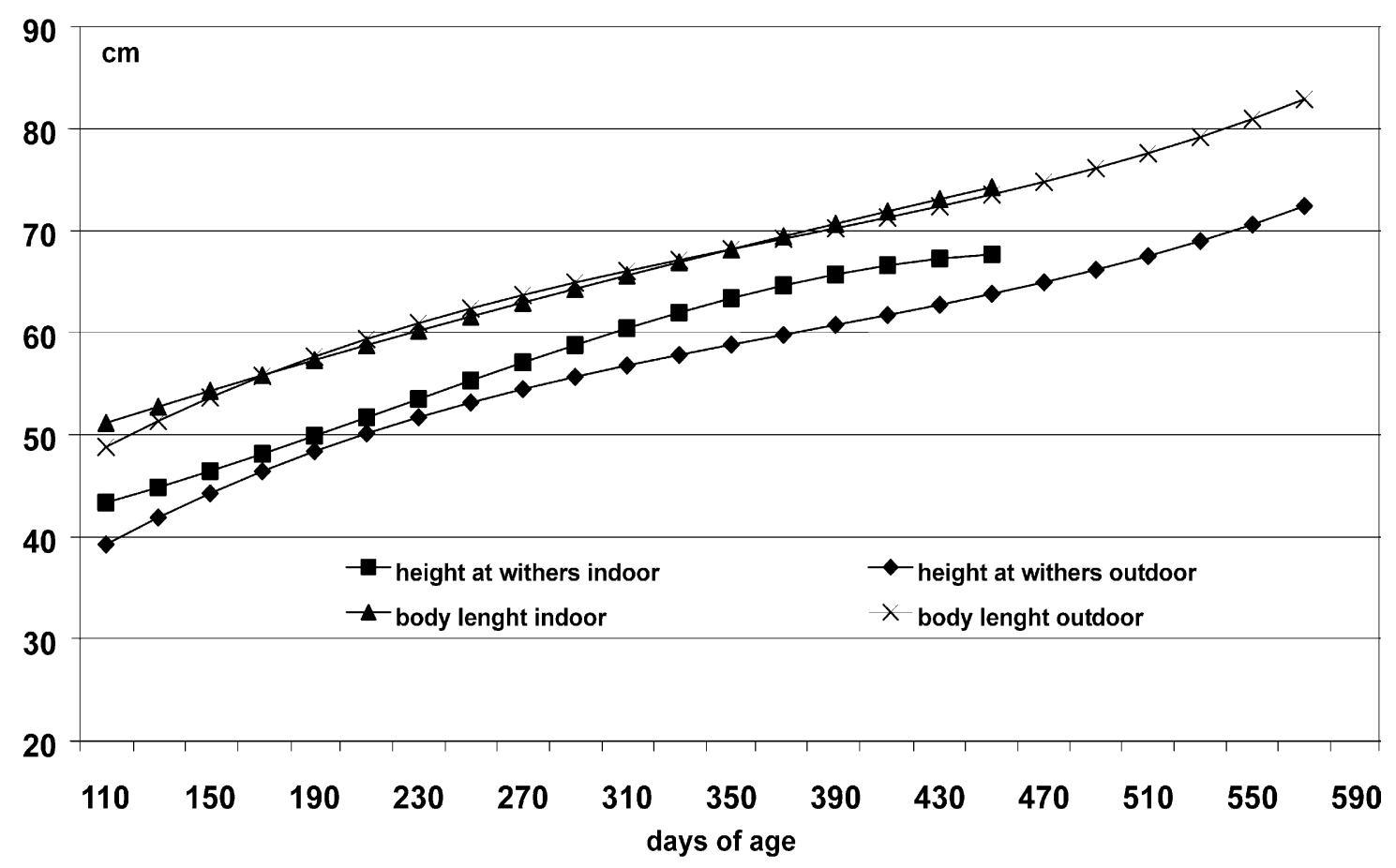

Fig. 2. Height at withers and body length in relation to age (days).

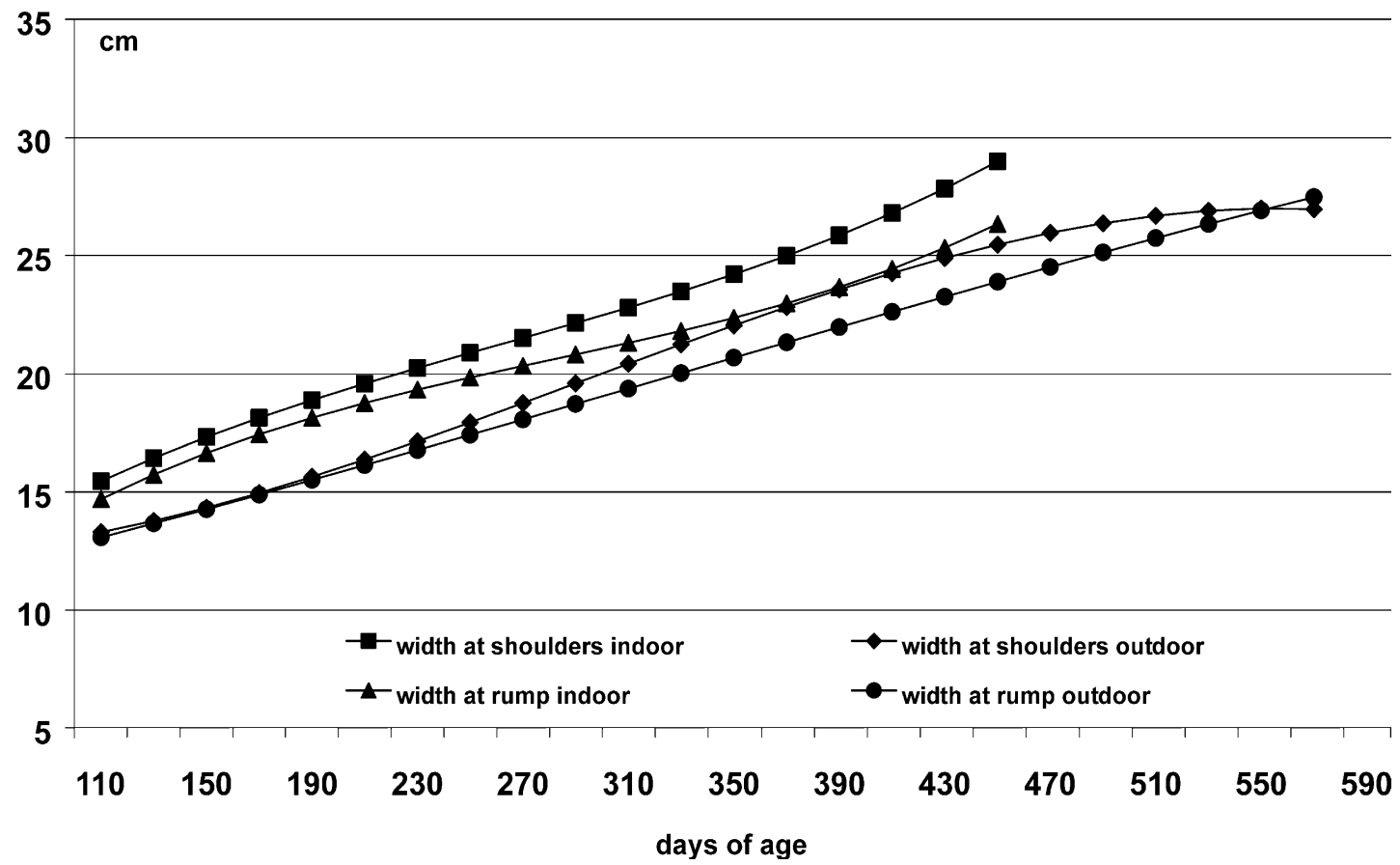

Fig. 3. Width at rump and shoulders in relation to age (days).

significantly greater in the outdoor group. To better explain these differences, estimates of body measurements at $100 \mathrm{~kg}$ live weight are given in Table 5. Pigs reared outdoors showed significant differences for height at withers, shoulder width and body length, which meant higher skeletal development related to the greater age of these animals. For the remaining body measurements, which are related to both skeletal and muscle development, differences between rearing systems were not significant. Carcass measurements are given in Table 6. In accordance to the observations on body length of live animals (Table 5), carcasses of similar weight were longer in outdoor than in indoor reated pigs. No differences were observed in thoracic depth. 


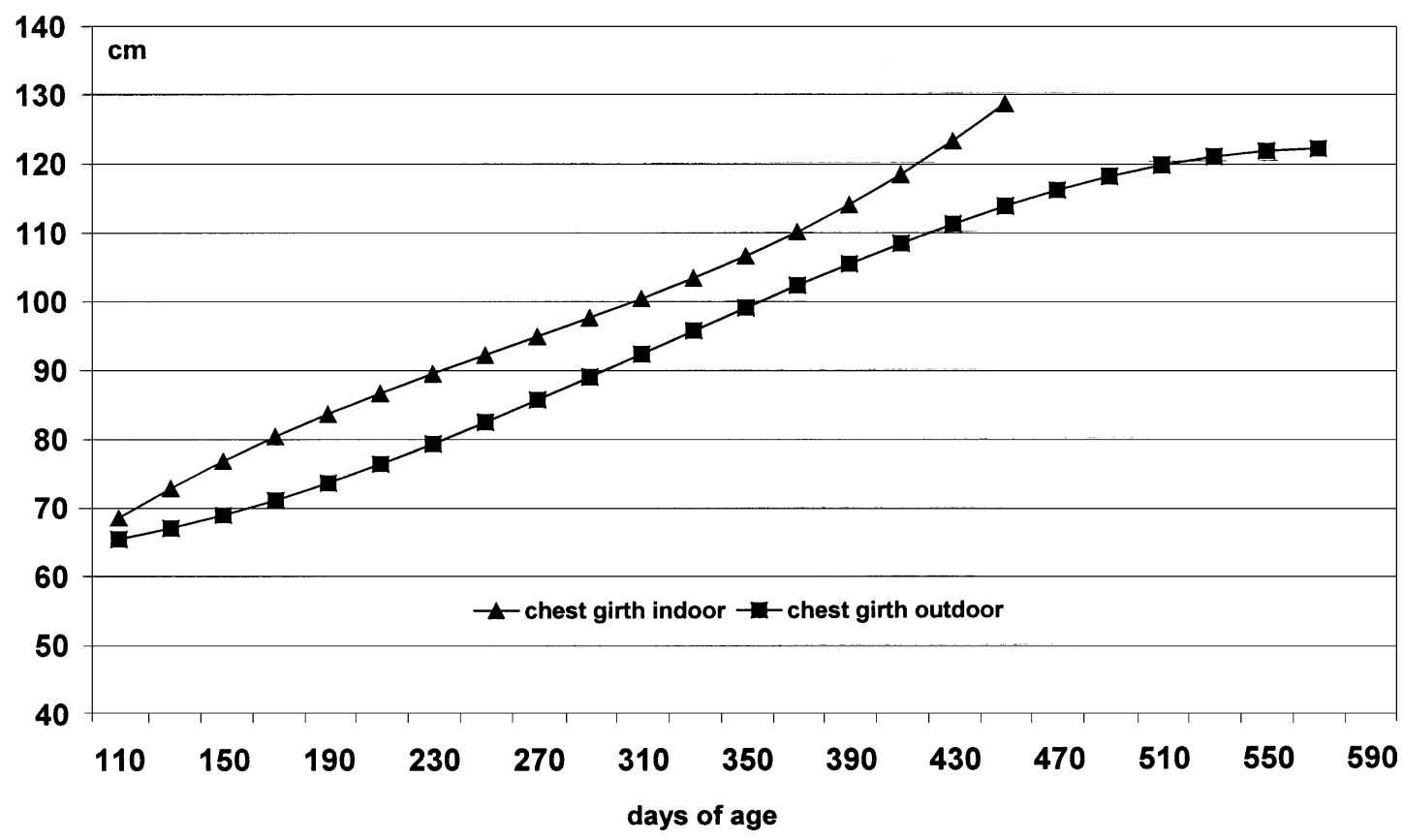

Fig. 4. Chest girth in relation to age (days).

Table 3

Live weight $(\mathrm{kg})$ and body measurements $(\mathrm{cm})$ estimated at 250, 350 and 450 days of age

\begin{tabular}{|c|c|c|c|c|c|c|c|c|c|c|}
\hline \multirow[t]{2}{*}{ Days of age } & \multicolumn{3}{|l|}{250} & \multicolumn{3}{|l|}{350} & \multicolumn{3}{|l|}{450} & \multirow[t]{2}{*}{ RSD } \\
\hline & Indoor & Outdoor & Significance & Indoor & Outdoor & Significance & Indoor & Outdoor & Significance & \\
\hline Live weight & 48.30 & 38.86 & $P<0.01$ & 72.41 & 59.68 & $P<0.01$ & 105.71 & 80.55 & $P<0.01$ & 11.44 \\
\hline Height at withers & 55.27 & 53.21 & $P<0.01$ & 63.22 & 58.94 & $P<0.01$ & 67.30 & 64.03 & $P<0.01$ & 5.45 \\
\hline Shoulder width & 20.89 & 17.99 & $P<0.01$ & 24.23 & 22.24 & $P<0.01$ & 29.01 & 25.88 & $P<0.01$ & 2.19 \\
\hline Rump width & 19.86 & 17.43 & $P<0.01$ & 22.40 & 20.70 & $P<0.01$ & 26.39 & 23.93 & $P<0.01$ & 2.10 \\
\hline Body length & 61.59 & 62.52 & n.s & 68.13 & 68.12 & n.s. & 74.10 & 73.27 & n.s. & 6.77 \\
\hline Chest girth & 92.32 & 83.51 & $P<0.01$ & 106.58 & 99.36 & $P<0.01$ & 128.51 & 113.52 & $P<0.01$ & 8.08 \\
\hline
\end{tabular}

Table 4

Mean allometric coefficients (b) of body measurements in relation to live weight

\begin{tabular}{llllll}
\hline & \multicolumn{2}{l}{ Indoor } & \multicolumn{2}{c}{ Outdoor } & \multirow{2}{*}{ Significance } \\
\cline { 2 - 5 } & $\mathrm{b}$ & S.E. & b & S.E. & \\
\hline Height at withers & 0.297 & 0.007 & 0.348 & 0.005 & $P<0.01$ \\
Shoulder width & 0.384 & 0.008 & 0.377 & 0.005 & n.s. \\
Rump width & 0.361 & 0.008 & 0.377 & 0.005 & n.s. \\
Body length & 0.269 & 0.007 & 0.286 & 0.005 & $P<0.05$ \\
Chest girth & 0.377 & 0.008 & 0.368 & 0.006 & n.s. \\
\hline
\end{tabular}

The greater length of outdoor animals was related to their greater ages, considering that physical exercise did not seem to influence skeletal development (Enfält, Lundström, Hansson, Karlsson, Essèn-Gustavsson, \& Håkansson, 1993). Generally, pigs reared indoors showed greater fat thickness than the outdoor ones. Thicker fat in indoor pigs at the first thoracic vertebra was due to the inner layer, while the higher value over the M. gluteus medius was due to the outer layer only. The lower backfat thickness of outdoor pigs may be related to the slower growth rate, at the same carcass weight, according to others (Enfält et al., 1997; Warriss, Kestin, \& Robinson, 1983) which demonstrated that slower growing pigs favour muscle deposition with respect to fat, resulting in leaner carcasses. Dressing and carcass composition are given in Table 7. No significant differences were found for dressing and loin percentages. Outdoor animals showed an higher percentage of lean cuts, in particular for ham and shoulder, but not for neck and loin. Enfält et al. (1997) suggested that outdoor rearing would induce greater development of glycolytic muscles, particularly muscles of the ham, and would not affect the growth of $\mathrm{M}$. longissimus dorsi. Outdoor pigs had less backfat, but more kidney fat. No significant differences were observed for the two other fat cuts, belly and jowl, or for total bone cuts. These results differed from those of a trial on Cinta Senese pigs reared outdoor and indoor, where the former 
Table 5

Body measurements $(\mathrm{cm})$ estimated at $100 \mathrm{~kg}$ of live weight

\begin{tabular}{lrrr}
\hline & Indoor & Outdoor & Significance \\
\hline Height at withers & 68.59 & 71.99 & $P<0.01$ \\
Shoulder width & 27.70 & 26.92 & $P<0.01$ \\
Rump width & 25.48 & 25.76 & n.s. \\
Body length & 74.59 & 80.48 & $P<0.01$ \\
Chest girth & 121.88 & 121.03 & n.s. \\
\hline
\end{tabular}

Table 6

Carcass traits $^{\mathrm{a}}$

\begin{tabular}{|c|c|c|c|c|c|}
\hline & & Indoor & Outdoor & Significance & RSD \\
\hline Carcass length & $\mathrm{cm}$ & 73.21 & 76.37 & $P<0.01$ & 3.437 \\
\hline Chest deep & $\mathrm{cm}$ & 20.05 & 19.94 & n.s. & 1.524 \\
\hline \multicolumn{6}{|c|}{ Backfat thickness } \\
\hline \multicolumn{6}{|c|}{$1^{\circ}$ thoracic vertebra } \\
\hline outer layer & $\mathrm{mm}$ & 18.29 & 17.43 & n.s. & 4.553 \\
\hline inner layer & $\mathrm{mm}$ & 37.22 & 31.70 & $P<0.01$ & 6.06 \\
\hline total & $\mathrm{mm}$ & 55.51 & 49.13 & $P<0.01$ & 7.129 \\
\hline \multicolumn{6}{|c|}{ Backfat thickness } \\
\hline \multicolumn{6}{|c|}{ last thoracic vertebra } \\
\hline outer layer & $\mathrm{mm}$ & 16.18 & 14.55 & n.s. & 3.034 \\
\hline inner layer & $\mathrm{mm}$ & 20.81 & 17.91 & $P=0.06$ & 4.948 \\
\hline total & $\mathrm{mm}$ & 36.99 & 32.46 & $P=0.02$ & 6.052 \\
\hline \multicolumn{6}{|c|}{ Backfat thickness } \\
\hline \multicolumn{6}{|c|}{ Gluteus medius } \\
\hline outer layer & $\mathrm{mm}$ & 26.39 & 21.5 & $P<0.01$ & 5.071 \\
\hline inner layer & $\mathrm{mm}$ & 18.15 & 17.85 & n.s. & 4.373 \\
\hline total & $\mathrm{mm}$ & 44.54 & 39.44 & $P=0.03$ & 7.610 \\
\hline
\end{tabular}

${ }^{\text {a }}$ Means estimated at average carcass weight of $77.85 \mathrm{~kg}$

Table 7

Dressing and carcass composition percentages ${ }^{\mathrm{a}}$

\begin{tabular}{lcccl}
\hline & Indoor & Outdoor & Significance & RSD \\
\hline Dressing & 82.51 & 81.86 & n.s. & 2.2 \\
Loin & 13.4 & 13.07 & n.s. & 1.297 \\
Ham & 21.07 & 22.38 & $P<0.01$ & 1.377 \\
Shoulder & 12.48 & 13.03 & $P<0.01$ & 0.715 \\
Neck & 6.80 & 6.86 & n.s. & 0.687 \\
Lean cuts & 53.84 & 55.48 & $P=0.08$ & 3.058 \\
Backfat & 15.17 & 13.06 & $P<0.01$ & 2.188 \\
Belly & 13.12 & 12.73 & n.s. & 1.226 \\
Jowl & 6.65 & 6.90 & n.s. & 0.876 \\
Kidney fat & 3.83 & 4.89 & $P<0.01$ & 1.218 \\
Fat cuts & 39.42 & 37.74 & n.s. & 3.487 \\
Head & 4.97 & 4.93 & n.s. & 0.564 \\
Feet & 1.66 & 1.84 & $P<0.01$ & 0.256 \\
Bone cuts & 6.62 & 6.77 & n.s. & 0.716 \\
\hline
\end{tabular}

a Means estimated at average carcass weight of $77.85 \mathrm{~kg}$

showed a higher percentage of fat cuts (Franci et al., 2001; Acciaioli et al., 2002). However, Cinta Senese pigs were slaughtered at live weights greater than those in this trial. Carcass composition of local pigs seemed to be influenced by the weight/age ratio which is related to the rearing system (Franci, Pugliese, Bozzi, Acciaioli, Campodoni, \& Gandini, 2000).

Sex did not significantly affect any of the analysed parameters except width at shoulders $(27.08 \mathrm{~cm}$ in males and $27.58 \mathrm{~cm}$ in females at $100 \mathrm{~kg}$ body weight), percentage of ham (22.11 in males and $21.33 \%$ in females) and kidney fat (3.98 males and $4.74 \%$ in females). Sex effects were probably reduced by castration of both males and females, as reported by Mayoral et al. (1999) for castrated male and female Iberian pigs.

\section{Conclusions}

The slower growth rate of outdoor versus indoor pigs affected their body dimensions. At the same age, outdoor pigs were smaller than indoor animals. Moreover, the allometric study showed that, at the same live weight, because of their older ages, the outdoor pigs had greater skeletal development, confirming that this is more related to age than body weight. The rearing system also affected carcass characteristics. Outdoor pigs were leaner, mainly because of higher shoulder and ham development. Taking the performances of pigs in the 
indoor system as the potential of the breed, this study shows that the traditional free-range system could be improved by providing feed integration during the critical periods of low wood productivity. The optimisation of traditional farming should increase the economic profitability of the breed, thus removing the danger of its decline. However, the optimisation process should retain the specific values of the traditional farming, including its social role, the favourable interactions with landscape and woods management, the associated cultural values and the characteristics of the typical meat products traditionally linked to this breed.

\section{References}

Acciaioli, A., Pugliese, C., Bozzi, R., Campodoni, G., Franci, O., \& Gandini, G. (2002). Productivity of Cinta Senese and Large White $\times$ Cinta Senese pigs reared outdoor on woodlands and indoor. 1 . Growth and somatic development. Zootecnica e Nutrizione Animale, 1 (3), 171-180.

ASPA. Asociazione Scientifica Produzione Animale. (1991). Metodologie relative alla macellazione degli animali di interesse zootecnico e alla valutazione e dissezione della loro carcassa. Roma: ISMEA.

Berger, F., Dagorn, J., Le Denmat, M., Quillien, J. P., Vaudelet, J. C., \& Signoret, J. P. (1997). Perinatal losses in outdoor pig breeding. A survay of factors influencing piglet mortality. Annales de Zoothecnie, $46,321-329$

Campodoni, G., Acciaioli, A., Bozzi, B., Pugliese, C., \& Franci, O. (1998). Caratterizzazione della razza suina Cinta Senese: primi risultati sull'accrescimento e sullo sviluppo morfologico. Rivista di Suinicoltura, 7, 79-83.

Chiofalo, V., \& Zumbo, A. (2001). Influence of dietary fat on the metabolic profile of "Siciliana" pig. In Proceeding of the A.S.P.A. XIV Congress (pp. 359-361), 12-15 June, Firenze.

Dobao, M. T., Rodrigagñez, J., Silio, L., \& Toro, M. A. (1988). Iberian pig production in Spain. Pig News and information, 9(3), 277-282.

Enfält, A. C., Lundström, K., Hansson, I., Karlsson, A., Essèn-Gustavsson, B., \& Håkansson, J. (1993). Moderate indoor exercise: effect on production and carcass traits, muscle enzyme activities and meat quality in pigs. Animal Production, 57, 127-135.

Enfält, A. C., Lundström, K., Hansson, I., Lundeheim, N., \& Nyström, P. E. (1997). Effects of outdoor rearing and sire breed (Duroc or Yorkshire) on carcass composition and sensory and technological meat quality. Meat Science, 45, 1-15.

Franci, O., Gandini, G., Madonia, G., Pugliese, C., Chiofalo, V., Bozzi, R., Acciaioli, A., Campodoni, G., \& Pizzi, F. (2001). Performances of Italian local breeds. In X. Ollivier, X. Labroue,
X. Glodek, X. Gandini, \& X. Delgado (Eds.), Characterisation and conservation of pig genetic resources. Wageningen: Wageningen Pers.

Franci O., Pugliese C., Bozzi R., Acciaioli A., Campodoni G., \& Gandini G. (2000). Effects of outdoor rearing on the performances of Cinta Senese pigs and their crosses with Large White. In Proceeding of EEAP-51th Annual Meeting (p. 58), 21-24 August 2000, The Hague The Netherlands.

Gandini, G., \& Giacomelli, P. (1997). What economic value for local livestock breeds? In Proceeding of 48th Annual Meeting of EAAP. Wageningen.

Gandini, G., Fortina, F., Franci, O., Madonia, G., \& Matassino, D. (2001). Pig genetic resources of Italy. In L. Ollivier, F. Labroue, P. Glodek, G. Gandini, \& J. V. Delgado (Eds.), Characterisation and conservation of pig genetic resources, Vol. 104(EEAP pub) (pp. 33-40). Wageningen: Wageningen Pers.

Huxley, J. S. (1932). Problems of relative growth. London: Methuen.

Jonsäll, A., Johansson, L., \& Lundström, K. (2001). Sensory quality and cooking loss of ham muscle (M. biceps femoris) from pigs reared indoors and outdoors. Meat Science, 57, 245-250.

Labroue, F., Goumy, S., Gruand, J., Mourot, J., Neelz, V., \& Legault, C. (2000). Comparaison au Large White de quatre races locales porcines française pour les performances de croissance, de carcasse et de qualité de la viande. Journées Recherche Porcine en France, 32, 403-411.

Legault, C., Audiot, A., Daridan, D., Gruand, J., Lagant, H., Luquet, M., Molènat, M., Rouzade, D., \& Simon, M. N. (1996). Recherche de références sur la possibilités de valoriser les porcs Gascon et Limousine par des produits de qualité. 1. Engraissement, carcasses, coûts de production. (1996). Journées Recherche Porcine en France, $28,115-122$.

Mayoral, A. I., Dorado, M., Guillèn, M. T., Vivo, J. M., Vàzquez, C., \& Ruiz, J. (1999). Development of meat and carcass quality characteristics in Iberian pigs reared outdoors. Meat Science, 52, 315-324.

Ruane, J.. In J. K. Oldenbroek (Ed.), Selecting breeds for conservation in genebanks and the management of farm animal genetic resourches (pp. 59-73). The Netherland: I.D.- DLO Lelystad.

SAS. (1997). SAS/STAT User's guide. 6.12 version. Cary, NC, USA: SAS Institute Inc.

Serra, X., Gil, F., Pérez Enciso, M., Oliver, M. A., Vàzquez, J. M., Gispert, M., Diaz, I., Moreno, F., Latorre, R., \& Noguera, J. L. (1998). A comparison of carcass, meat quality amd histochemical charactristics of Iberian (Guadyerbas line) and Landrace pigs. Livestock Production Science, 56, 215-223.

Van der Wal, P. G., \& Mateman, G. (1993). 'Scharrel' (free range) pigs: Carcass composition, meat quality and taste-panel studies. Meat Science, 34, 27-37.

Walstra, P. (1980). Growth and carcass composition from birth to maturity in relation to feeding level and sex in Dutch Landrace pigs. Wageningen: Veenman H. e Zonen B.V.

Warris, P. D., Kestin, S. C., \& Robinson, J. M. (1983). A note on the influence of rearing environment on meat quality in pigs. Meat Science, 9, 271-279. 